\title{
PENGEMBANGAN SISTEM E-LEARNING DI STT TERPADU NURUL FIKRI MENGGUNAKAN MOODLE
}

\author{
Suhendi \\ Program Studi Sistem Informasi STT Terpadu Nurul Fikri, suhendi@ nurulfikri.ac.id \\ Syahrul Huda \\ Program Studi Sistem Informasi STT Terpadu Nurul Fikri, aroel_clv2@ymail.com
}

\begin{abstract}
Abstrak
Penggunaan sistem e-learning sebagai media pembelajaran sangatlah berkembang pesat di era globalisasi saat ini. STT Terpadu Nurul Fikri sendiri sudah menerapkan sistem e-learning menggunakan moodle versi 2.3 dalam menunjang proses belajar-mengajar. Namun dalam penerapannya masih terdapat beberapa permasalahan pada sistem e-learning tersebut. Diperlukan pengembangan sistem e-learning di STT Terpadu Nurul Fikri menggunakan moodle versi 2.9 yang bertujuan untuk mengoptimalkan proses belajar-mengajar dan memudahkan penggunanya. Metode pengembangan sistem yang digunakan dalam penelitian ini adalah Rapid Application Development (RAD) dan Unified Modeling Language (UML). Adapun fase dalam metode pengembangan sistem $R A D$ tersebut meliputi requirement planning, user design, contruction dan cutover. UML digunakan sebagai alat bantu modeling yang hanya meliputi tahapan use case dan activity diagram. Hasil dari kegiatan penelitian ini adalah sistem e-learning di STT Terpadu Nurul Fikri menggunakan moodle versi 2.9 dengan tingkat pengujian melalui kuesioner 78,7\% (kuat) dapat dikatakan layak untuk diterapkan di STT Terpadu Nurul Fikri.Hasil penelitian bisa dapat diakses melalui alamat url berikut : http:// elen.nurulfikri.ac.id/.
\end{abstract}

Kata Kunci: Pengembangan, Sistem,E-learning, Moodle

\section{PENDAHULUAN}

STT Terpadu Nurul Fikri sudah menerapkan pembelajaran secara online sejak mulai berdirinya di tahun 2012. Implementasi penerapan pembelajaran secara online menggunakan Moodle yang belum responsive sehingga perlu pengembangan lebih lanjut.

Latar belakang penelitian sebagai responsive atas penelitian sebelumnya yang penulis lakukan, dimana tampilan web e-learning STT Terpadu Nurul Fikri dapat kategorikan cukup dari sisi tampilan sehingga perlu dilakukan pengembangan sistem lebih lanjut [1].

Namun dalam penerapannya, sistem e-learning di STT Terpadu Nurul Fikri yang ada saat ini masih terdapat beberapa permasalahan seperti : (1) Tampilan web dari sistem e-learning masih kurang menarik dan belum responsive; (2) Akses ke matakuliah yang telah diambil oleh pengguna (dosen dan mahasiswa) masih menyulitkan; dan (3) Belum adanya menu untuk akses ke sistem informasi lainnya yang ada di STT Terpadu Nurul Fikri (Journal, Library, Repository).
Berdasarkan uraian permasalahan sistem e-learning tersebut, maka penelitian ini akan difokuskan pada bagaimana mengembangkan sistem e-learning di STT Terpadu Nurul Fikri menggunakan moodle. Penggunaan moodle untuk kebutuhan pengembangan sistem e-learning sendiri dipilih karena : (1) Moodle versi 2.9 sudah responsive, sehingga tampilannya sudah menyesuaikan dengan perangkat yang digunakan seperti pc desktop, laptop dan gadget lainnya; dan (2) Moodle versi 2.9 sangat mudah dalam penggunaannya, terlebih pada saat pengaturan berupa penambahan menu dan letak block (Clock, Login, Main menu.). Hasil yang diharapkan dari kegiatan penelitian ini adalah penerapan sistem e-learning di STT Terpadu Nurul Fikri ke depannya dapat lebih baik, sehingga tujuan untuk mengoptimalkan proses belajar-mengajar dan memudahkan penggunanya dapat terealisasikan, serta diharapkan dapat memberikan kontribusi yang positif bagi STT Terpadu Nurul Fikri.

Perumusan masalah yang diangkat pada penelitian ini yaitu "Bagaimana mengembangkan sistem $e$ learning di STT Terpadu Nurul Fikri menggunakan 
moodle?". Perumusan masalah tersebut akan dijawab berdasarkan kajian atas hal-hal berikut, antara lain :

1. Bagaimana kondisi dari penerapan sistem $e$ learning di STT Terpadu Nurul Fikri yang ada saat ini?

2. Masukan apa saja yang diperlukan untuk kebutuhan pengembangan sistem e-learning di STT Terpadu Nurul Fikri?

3. Bagaimana mengembangkan sistem e-learning di STT Terpadu Nurul Fikri menggunakan moodle versi 2.9?

4. Bagaimana efektifitas sistem e-learning di STT Terpadu Nurul Fikri yang telah dikembangkan?

Tujuan dan manfaat dari penelitian ini, antara lain :

a.Mengetahui kondisi dari penerapan sistem e-learning di STT Terpadu Nurul Fikri yang ada saat ini.

b.Menganalisis masukan yang diperlukan berdasarkan hasil wawancara untuk kebutuhan pengembangan sistem e-learning di STT Terpadu Nurul Fikri.

c.Mengembangkan dan menerapkan sistem e-learning di STT Terpadu Nurul Fikri menggunakan moodle versi 2.9.

d.Mengetahui efektifitas sistem e-learning di STT Terpadu Nurul Fikri yang telah dikembangkan.

Agar pembahasan penelitian ini lebih terarah, maka ditentukan batasan masalahnya, antara lain :

1. Pengembangan sistem e-learning di STT Terpadu Nurul Fikri menggunakan moodle versi 2.9.

2. Pengembangan sistem e-learning di STT Terpadu Nurul Fikri disesuaikan dengan masukan berdasarkan hasil wawancara dengan pihak Puket I Bidang Akademik STT Terpadu Nurul Fikri.

3. Pengembangan sistem e-learning di STT Terpadu Nurul Fikri menggunakan metode pengembangan sistem $R A D$ dan $U M L$ sebagai alat bantu modeling yang hanya meliputi tahapan use case dan activity diagram.

Teori dasar dalam penelitian ini menggunakan beberapa teori seperti : teori sistem informasi, teori analisis pengembangan sistem, teori mengenai $e$ - learning, dan teori mengenai metode pengembangan menggunakan RAD (Rapid Application Development).

\section{METODOLOGI PENELITIAN}

\section{Metode Pengumpulan Data}

Dalam penelitian ini, penulis mendapatkan data-data yang dibutuhkan melalui beberapa metode pengumpulan data yang meliputi studi pustaka dan studi lapangan.

\section{Studi Pustaka}

Mencari informasi dan melakukan penelitian melalui buku-buku, artikel dan literatur penelitian sejenis di internet yang berkaitan erat dengan objek penelitian yang penulis bahas, yaitu mengenai pengembangan sistem e-learning menggunakan moodle.

\section{Studi Lapangan}

Mengumpulkan data-data yang diperlukan untuk kebutuhan analisis sistem melalui studi lapangan. Adapun teknik pengumpulan data yang penulis lakukan dalam penelitian ini, antara lain :

1. Observasi : Merupakan teknik pengumpulan data yang cukup efektif dengan mengamati dan mempelajari kondisi dari penerapan sistem $e$ learning di STT Terpadu Nurul Fikri yang ada saat ini. Dalam hal ini penulis melakukan pengamatan terhadap beberapa hal, antara lain :

a. Dokumen-dokumen yang mampu menggambarkan profil STT Terpadu Nurul Fikri, sehingga penulis dapat melakukan perencanaan identifikasi masalah dalam proses penelitian selanjutnya.

b. Pengamatan langsung terhadap kondisi dari penerapan sistem e-learning di STT Terpadu Nurul Fikri yang ada saat ini, sehingga penulis mampu menganalisis permasalahan dari sistem e-learning sebagai bahan evaluasi untuk pengembangan sistem e-learning yang akan dilakukan. 
c. Pengamatan juga dilakukan pada beberapa sistem e-learning di perguruan tinggi lainnya sebagai benchmark seperti : (1) E-learning Universitas Indonesia dengan alamat url berikut : https://scele.ui.ac.id/; dan (2) E-learning STMIK Amikom dengan alamat url berikut : http://elarning.amikom.ac.id/.

2. Wawancara : Merupakan teknik pengumpulan data yang banyak dilakukan dalam pengembangan sistem dengan melakukan tanya-jawab dan meminta masukan yang diperlukan untuk kebutuhan pengembangan sistem e-learning di STT Terpadu Nurul Fikri. Bapak Sirojul Munir, S.Si., M.Kom. selaku Puket I Bidang Akademik STT Terpadu Nurul Fikri merupakan pihak yang penulis wawancarai dalam penelitian ini. Wawancara yang dilakukan terkait dengan melakukan tanya-jawab dan meminta masukan yang diperlukan untuk kebutuhan pengembangan sistem e-learning di STT Terpadu Nurul Fikri.

3. Kuesioner : Merupakan media dokumentasi yang cukup baik dalam melakukan penelitian dengan membuat alat riset sederhana yang berisi serangkaian pertanyaan tertulis yang disebarkan kepada pengguna sistem e-learning di STT Terpadu Nurul Fikri. Kuesioner yang penulis gunakan dalam penelitian ini hanya terbatas pada pertanyaanpertanyaan mengenai tingkat evaluasi kepuasan pengguna terhadap efektifitas sistem e-learning yang telah dikembangkan. Perhitungan kuesioner dalam penelitian ini menggunakan metode penilaian skala Likert.

Hasil dari pengumpulan data yang dilakukan melalui observasi dan wawancara akan digunakan sebagai masukan yang diperlukan untuk kebutuhan pengembangan sistem e-learning di STT Terpadu Nurul Fikri. Sedangkan hasil perhitungan kuesioner akan digunakan untuk penilaian terhadap efektifitas sistem e-learning di STT Terpadu Nurul Fikri yang telah dikembangkan.

\section{Metode Pengembangan Sistem}

Dalam pengembangan sistem e-learning di STT Terpadu Nurul Fikri, penulis menggunakan metode pengembangan sistem $R A D$ dan $U M L$ sebagai alat bantu modeling untuk pengembangan sistem tersebut. Adapun langkah-langkah yang dilakukan dalam pengembangan sistem menggunakan metode pengembangan sistem $R A D$, yaitu requirement planning, user design, construction dan cutover.

\section{Requirement Planning}

Pada fase ini penulis merumuskan tujuan dan syaratsyarat informasi yang dibutuhkan dalam pengembangan sistem e-learning. Tahapan requirement planning yang dilakukan meliputi pengumpulan data, analisis sistem yang berjalan, identifikasi masalah dan usulan pemecahan masalah.

\section{User Design}

Setelah proses requirement planning dilakukan, maka fase selanjutnya yang penulis lakukan adalah merumuskan dan merancang sistem e-learning yang akan dibuat menggunakan UML. Tahapan user design yang dilakukan meliputi identifikasi aktor, use case dan activity diagram.

\section{Construction}

Pada fase ini penulis mengembangkan dan meningkatkan fungsi-fungsi yang telah disetujui oleh pengguna sistem e-learning dalam bentuk yang lebih menarik. Tahapan construction yang dilakukan meliputi kebutuhan sistem dan pengembangan sistem.

\section{Cutover}

Fase akhir atau final dalam menentukan apakah sistem e-learning yang telah dikembangkan akan digunakan untuk menggantikan sistem yang lama atau tidak di 
STT Terpadu Nurul Fikri dengan persetujuan pihak Puket I Bidang Akademik selaku owner project. Tahapan cutover yang dilakukan meliputi pengujian sistem dan launching sistem.

\section{Tempat / Lokasi Penelitian}

Penelitian ini dilaksanakan di Kampus B STT Terpadu Nurul Fikri yang beralamat di jalan Lenteng Agung Raya No. 20, Kel. Lenteng Agung Kec. Jagakarsa, Jakarta Selatan - 12640 .

\section{Kerangka Berfikir}

Berikut ini adalah kerangka berfikir berdasarkan metode pengembangan sistem $R A D$ dan $U M L$ :

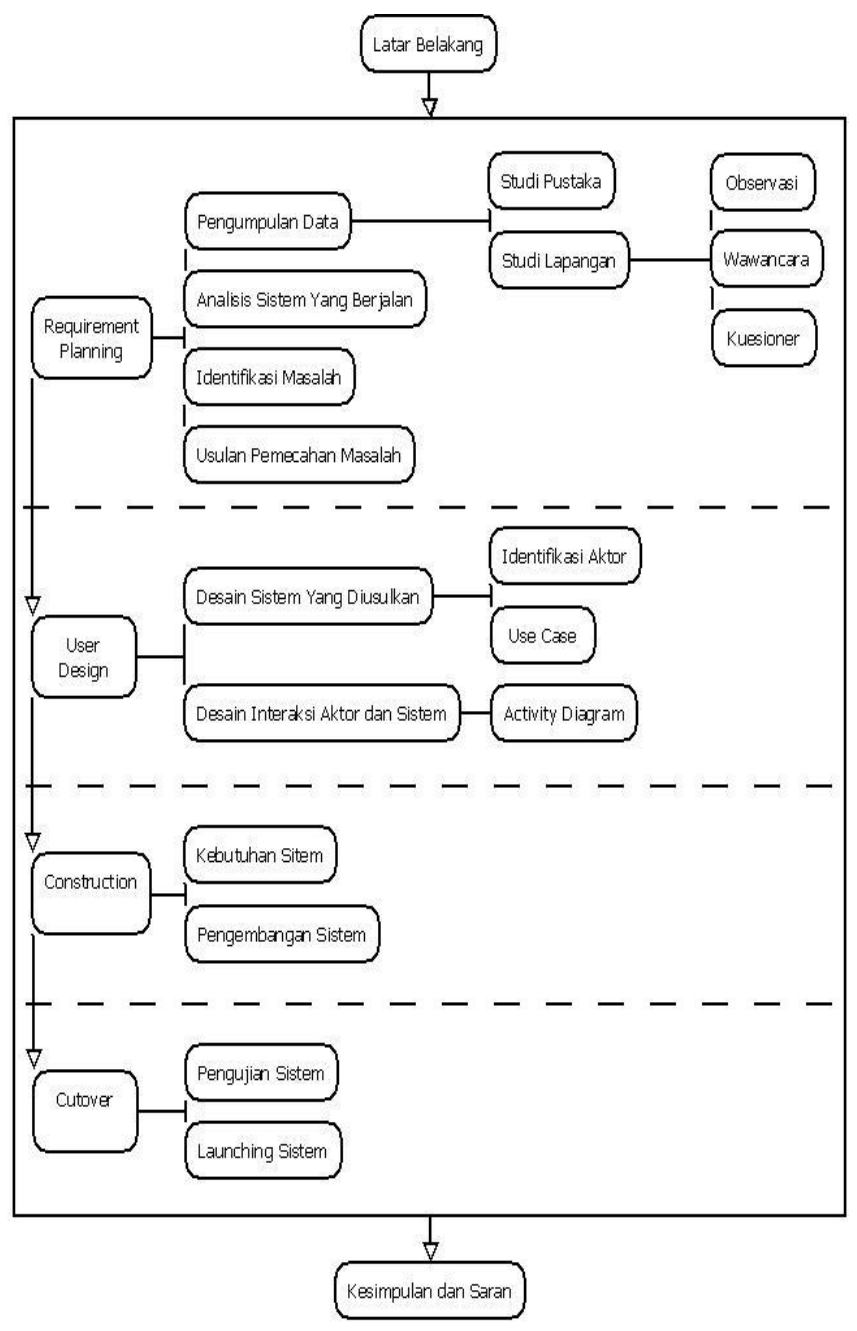

Gambar.1 Kerangka berfikir pengembangan sistem

\section{URAIAN PENELITIAN}

Analisis dan perancangan dalam penelitian ini dilakukan dalam beberapa tahap sesuai dengan metode pengembangan sistem. Pertama yang akan dilakukan adalah melakukan requirement planning salah satu yang terpenting adalah melakukan kuesioner awal untuk mendapatkan pendapat dari responden yang terdiri dari 10 Dosen dan 73 Mahasiswa, hasil dari kuesioner awal adalah sebagai berikut :

1. Apakah anda setuju apabila tampilan pada sistem $e$ learning diubah menjadi lebih menarik dan responsive?

Tabel.1 Pertanyaan pertama

\begin{tabular}{|c|l|c|c|}
\hline No & \multicolumn{1}{|c|}{$\begin{array}{c}\text { Alternatif } \\
\text { Jawaban }\end{array}$} & Jumlah & Persentase \\
\hline 1 & Sangat Setuju & 47 & $56.6 \%$ \\
\hline 2 & Setuju & 36 & $43.4 \%$ \\
\hline 3 & Tidak Setuju & 0 & $0 \%$ \\
\hline 4 & $\begin{array}{l}\text { Sangat Tidak } \\
\text { Setuju }\end{array}$ & 0 & $0 \%$ \\
\hline \multicolumn{2}{|c|}{ Total } & $\mathbf{8 3}$ & $\mathbf{1 0 0 \%}$ \\
\hline
\end{tabular}

Interpretasi skor soal no. 1 : (296 / 332) x $100=$ $89.1 \%$

2. Apakah anda setuju apabila pemanfaatan pada sistem e-learning menjadi lebih optimal?

Tabel.2 Pertanyaan kedua

\begin{tabular}{|c|l|c|c|}
\hline No & \multicolumn{1}{|c|}{$\begin{array}{c}\text { Alternatif } \\
\text { Jawaban }\end{array}$} & Jumlah & Persentase \\
\hline 1 & Sangat Setuju & 43 & $51.8 \%$ \\
\hline 2 & Setuju & 40 & $48.2 \%$ \\
\hline 3 & Tidak Setuju & 0 & $0 \%$ \\
\hline 4 & $\begin{array}{l}\text { Sangat Tidak } \\
\text { Setuju }\end{array}$ & 0 & $0 \%$ \\
\hline \multicolumn{2}{|c|}{ Total } & $\mathbf{8 3}$ & $\mathbf{1 0 0 \%}$ \\
\hline
\end{tabular}

Interpretasi skor soal no. 2 : $(292 / 332) \times 100=$ $87.9 \%$ 
3. Apakah anda setuju apabila akses ke matakuliah yang anda ambil pada sistem e-learning menjadi lebih mudah?

Tabel.3 Pertanyaan ketiga

\begin{tabular}{|c|l|c|c|}
\hline No & \multicolumn{1}{|c|}{$\begin{array}{c}\text { Alternatif } \\
\text { Jawaban }\end{array}$} & Jumlah & Persentase \\
\hline 1 & Sangat Setuju & 52 & $62.7 \%$ \\
\hline 2 & Setuju & 31 & $37.3 \%$ \\
\hline 3 & Tidak Setuju & 0 & $0 \%$ \\
\hline 4 & $\begin{array}{l}\text { Sangat Tidak } \\
\text { Setuju }\end{array}$ & 0 & $0 \%$ \\
\hline \multicolumn{2}{|c|}{ Total } & $\mathbf{8 3}$ & $\mathbf{1 0 0} \%$ \\
\hline
\end{tabular}

Interpretasi skor soal no. 3 : (301/332) x $100=$ $90.6 \%$

4. Apakah anda setuju apabila fitur pada sistem $e$ learning menjadi lebih mudah dipahami?

Tabel.4 Pertanyaan keempat

\begin{tabular}{|c|l|c|c|}
\hline No & \multicolumn{1}{|c|}{$\begin{array}{c}\text { Alternatif } \\
\text { Jawaban }\end{array}$} & Jumlah & Persentase \\
\hline 1 & Sangat Setuju & 45 & $54.2 \%$ \\
\hline 2 & Setuju & 38 & $45.8 \%$ \\
\hline 3 & Tidak Setuju & 0 & $0 \%$ \\
\hline 4 & $\begin{array}{l}\text { Sangat Tidak } \\
\text { Setuju }\end{array}$ & 0 & $0 \%$ \\
\hline \multicolumn{2}{|c|}{ Total } & $\mathbf{8 3}$ & $\mathbf{1 0 0} \%$ \\
\hline
\end{tabular}

Interpretasi skor soal no. $4:(294 / 332) \times 100=88.5 \%$

5. Apakah anda setuju apabila dilakukan pengembangan pada sistem e-learning untuk perbaikan tampilan dan fitur?

Tabel.5 Pertanyaan kelima

\begin{tabular}{|c|l|c|c|}
\hline No & $\begin{array}{c}\text { Alternatif } \\
\text { Jawaban }\end{array}$ & Jumlah & Persentase \\
\hline 1 & $\begin{array}{l}\text { Sangat } \\
\text { Setuju }\end{array}$ & 45 & $54.2 \%$ \\
\hline 2 & Setuju & 38 & $45.8 \%$ \\
\hline
\end{tabular}

\begin{tabular}{|c|l|c|c|}
\hline No & $\begin{array}{c}\text { Alternatif } \\
\text { Jawaban }\end{array}$ & Jumlah & Persentase \\
\hline 3 & Tidak Setuju & 0 & $0 \%$ \\
\hline 4 & $\begin{array}{l}\text { Sangat Tidak } \\
\text { Setuju }\end{array}$ & 0 & $0 \%$ \\
\hline \multicolumn{2}{|c|}{ Total } & $\mathbf{8 3}$ & $\mathbf{1 0 0} \%$ \\
\hline
\end{tabular}

Interpretasi skor soal no. 5 : (294 / 332) x $100=$ $88.5 \%$

Penilaian skala Likert untuk interpretasi keseluruhan skor dari soal no. 1 sampai dengan $5:(89.1+87.9+$ $90.6+88.5+88.5) / 5=88.9 \%$

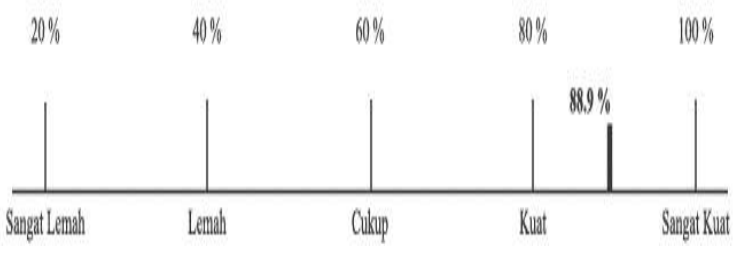

Gambar.2 Hasil Perhitungan Kuesioner awal

Berdasarkan hasil penilaian kuesioner tersebut, maka dapat disimpulkan bahwa pengembangan sistem $e$ learning di STT Terpadu Nurul Fikri memang diperlukan dengan tingkat evaluasi kepuasan pengguna diangka rata-rata $88.9 \%$ (kuat), sehingga tujuan untuk mengoptimalkan proses belajar-mengajar dan memudahkan penggunanya dapat terealisasikan.

\section{Analisis Sistem Yang Berjalan}

Berdasarkan hasil pengumpulan data yang telah dilakukan, maka penulis dapat menyimpulkan hasil analisis dari sistem e-learning di STT Terpadu Nurul Fikri yang ada saat ini.

Adapun hasil analisis dari sistem e-learning yang berjalan saat ini, antara lain :

1. Sistem e-learning sudah beroperasi selama kuranglebih 3 (tiga) tahun sejak pertama kali di-launching pada tahun 2012.

2. Sistem e-learning masih menggunakan moodle versi 2.3 dan belum pernah dilakukan 
pengembangan sistem e-learning ke moodle versi terbaru.

3. Engine database pada sistem e-learning menggunakan MyIsam.

4. Sistem e-learning belum mempunyai sistem backup data secara otomatis.

5. Server utama dari sistem e-learning terletak di kampus B STT Terpadu Nurul Fikri.

6. Sistem e-learning memerlukan pengembangan sistem untuk mengoptimalkan proses belajarmengajar dan memudahkan penggunanya.

\section{Identifikasi Masalah}

Pada tahapan ini penulis melakukan identifikasi masalah berdasarkan hasil pengumpulan data yang telah dilakukan mengenai permasalahan yang terdapat pada sistem e-learning di STT Terpadu Nurul Fikri yang ada saat ini.

Adapun permasalahan dari sistem e-learning yang penulis temukan selama penelitian berlangsung, antara lain :

1. Tampilan web dari sistem e-learning masih kurang menarik dan belum responsive .

2. Akses ke matakuliah yang telah diambil oleh pengguna masih menyulitkan.

3. Belum adanya menu untuk akses ke sistem informasi lainnya yang ada di STT Terpadu Nurul Fikri.

4. Terdapat error system (JSON) pada saat dosen meng-upload materi perkuliahan.

\section{Usulan Pemecahan Masalah}

Berdasarkan hasil identifikasi masalah yang telah dilakukan, maka diperlukan suatu usulan pemecahan masalah terhadap permasalahan tersebut, yang nantinya akan menjadi masukan untuk kebutuhan pengembangan e-learning di STT Terpadu Nurul Fikri.
Adapun pemecahan masalah yang penulis usulkan untuk kebutuhan pengembangan sistem e-learning tersebut, antara lain :

1. Pengembangan tampilan web dari sistem $e$ learning, yaitu dengan menggunakan moodle versi 2.9 yang sudah responsive, menggunakan theme yang sesuai dengan nuansa STT Terpadu Nurul Fikri dan mengatur letak block sesuai kebutuhan.

2. Penambahan menu dan block untuk mempermudah pengguna dalam mengakses matakuliah yang telah diambil.

3. Penambahan menu untuk akses ke sistem informasi lainnya yang ada di STT Terpadu Nurul Fikri.

4. Penambahan site upload limit pada pengaturan memory limit sistem e-learning.

\section{User Design}

Pada fase user design ini penulis melakukan perancangan sistem e-learning yang diajukan untuk memperbaiki permasalahan sistem e-learning yang telah dijelaskan pada fase sebelumnya. Fase user design tersebut meliputi identifikasi aktor, use case dan activity diagram.

\section{Identifikasi Aktor}

Aktor yang terlibat dalam sistem e-learning di STT Terpadu Nurul Fikri dapat diklasifikasikan menjadi 4 (empat) kategori, yaitu admin, baak, dosen dan mahasiswa. Adapun aktor yang terdapat pada sistem $e$ learning akan dijelaskan pada tabel berikut :

Tabel.6 Aktor yang terlibat

\begin{tabular}{|c|c|l|}
\hline No & Aktor & \multicolumn{1}{c|}{ Keterangan } \\
\hline 1 & Admin & $\begin{array}{l}\text { Merupakan } \text { user yang } \\
\text { memiliki wewenang tertinggi } \\
\text { dan dapat melakukan seluruh } \\
\text { aktifitas yang dilakukan oleh } \\
\text { aktor lainnya. Tugas utama } \\
\text { admin adalah meng-upload } \\
\text { user, membuat informasi dan } \\
\text { membuat matakuliah }\end{array}$ \\
\hline 2 & Baak & $\begin{array}{l}\text { Merupakan } \text { user yang hanya } \\
\text { memiliki wewenang untuk } \\
\text { melakukan aktifitas membuat } \\
\text { informasi. }\end{array}$ \\
\hline
\end{tabular}




\begin{tabular}{|c|c|c|}
\hline No & Aktor & Keterangan \\
\hline 3 & Dosen & $\begin{array}{l}\text { Merupakan } \text { user yang } \\
\text { memiliki wewenang untuk } \\
\text { melakukan aktifitas melihat } \\
\text { informasi, mengakses } \\
\text { matakuliah, meng-upload } \\
\text { materi, membuat kuis dan } \\
\text { membuat upload tugas. }\end{array}$ \\
\hline 4 & Mahasiswa & $\begin{array}{c}\text { Merupakan } \text { user yang } \\
\text { memiliki wewenang untuk } \\
\text { melakukan aktifitas melihat } \\
\text { informasi, meng-enrol } \\
\text { matakuliah, mengakses } \\
\text { matakuliah, men-download } \\
\text { materi, mengikuti kuis dan } \\
\text { meng-upload tugas. } \\
\end{array}$ \\
\hline
\end{tabular}

\section{Use Case Utama}

Pada use case utama, terdapat gabungan dari seluruh use case yang terlibat pada sistem e-learning berdasarkan perspektif user admin, baak, dosen dan mahasiswa.

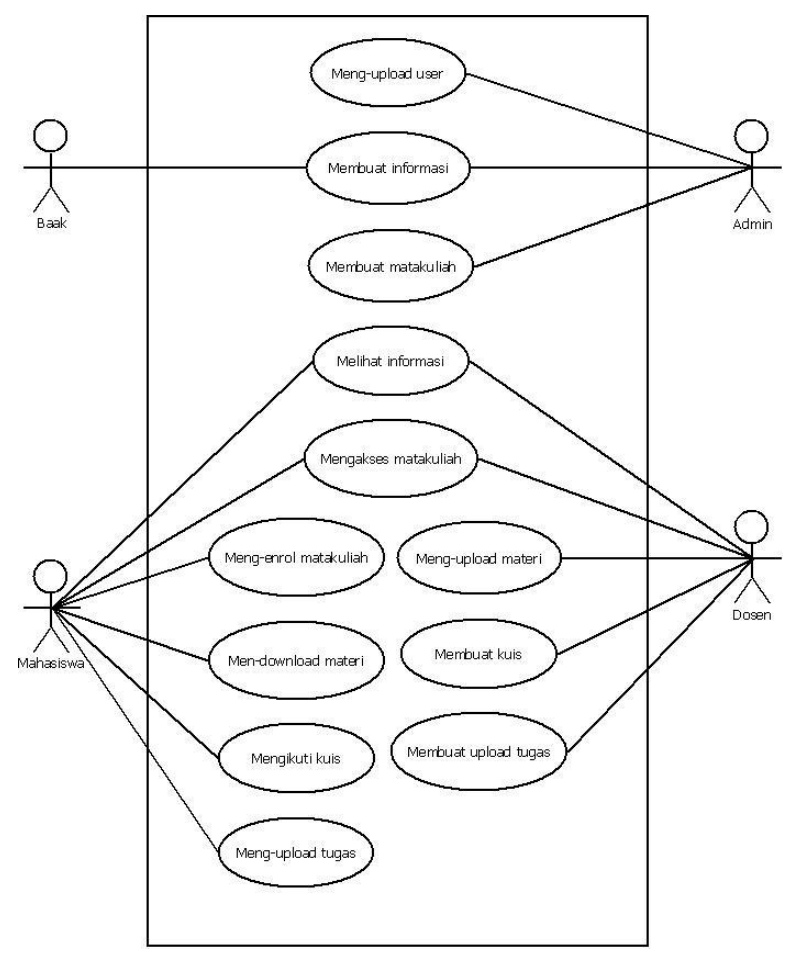

Gambar.3 Use case utama

\section{Activity Diagram}

Activity diagram merupakan representasi grafis yang memodelkan alur kerja suatu bisnis dan urutan aktifitas pada suatu proses. Adapun activity diagram tersebut meliputi activity diagram meng-upload user, activity diagram membuat informasi, activity diagram melihat informasi, activity diagram membuat matakuliah, activity diagram meng-enrol matakuliah, activity diagram mengakses matakuliah, activity diagram meng-upload materi, activity diagram men-download materi, activity diagram membuat kuis, activity diagram mengikuti kuis, activity diagram membuat upload tugas dan activity diagram meng-upload tugas.

\section{Activity Diagram Membuat Informasi}

Pada activity diagram membuat informasi, terdapat alur proses dari interaksi antara admin dan baak dengan sistem e-learning pada aktifitas membuat informasi.

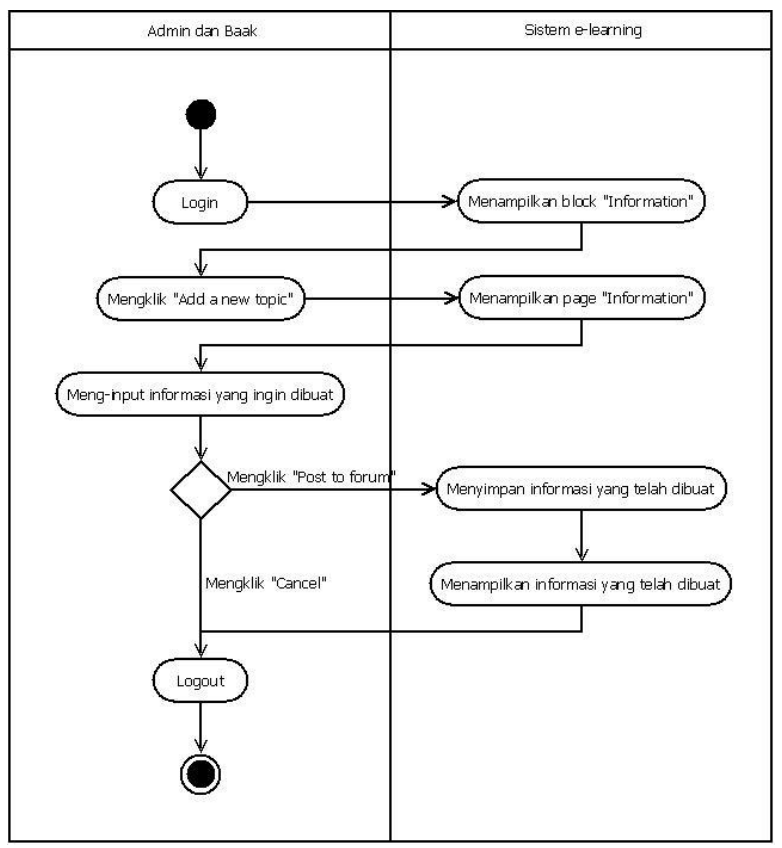

Gambar.4 Activity diagram membuat informasi

\section{Activity Diagram Mengakses Matakuliah}

Pada activity diagram mengakses matakuliah, terdapat alur proses dari interaksi antara dosen dan mahasiswa dengan sistem e-learning pada aktifitas mengakses matakuliah. Aktifitas mengakses matakuliah diawali dengan login dilanjutkan dengan mycourses sehingga sistem akan menampilkan overview courses, user tinggal memilih matakuliah mana yang akan diakses sehingga sistem akan menampilkan matakuliah yang akan diakses. Aktifitas mengakses matakuliah akan berakhir apabila user akan memilih logout sehingga sistem akan memberikan tampilan logout. 


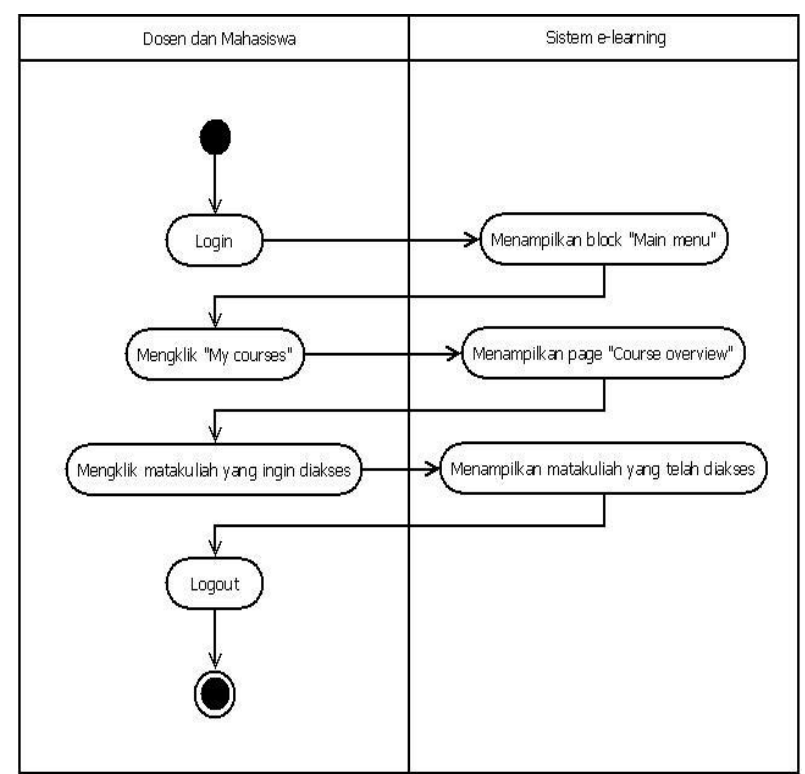

Gambar.5 Activity diagram mengakses matakuliah

\section{Construction}

Pada bagian ini akan dijelaskan mengenai fase construction yang meliputi kebutuhan sistem dan pengembangan sistem.

\section{Kebutuhan Sistem}

Dalam penerapan sistem e-learning di STT Terpadu Nurul Fikri membutuhkan perangkat pendukung berupa perangkat keras dan perangkat lunak. Adapun kebutuhan sistem tersebut diklasifikasikan ke dalam 3 (tiga) kategori yaitu server, client dan network.

\section{Server}

1. Perangkat Keras

a. PC Server dengan spesifikasi minimal sebagai berikut :

1) Processor Intel ${ }^{\circledR} X e o n^{\mathrm{TM}} \mathrm{E} 5410$

2) Harddisk $240 \mathrm{~GB}$

3) $R A M 3 \mathrm{~GB}$

4) $V G A 256 \mathrm{MB}$

2. Perangkat Lunak
a. Centos versi 5
b. Web server Apache versi 2.4.12
c. $P H P$ versi 5.4 .4
d. Database $M y S Q L$ versi 5.5.31
e. Mozilla Firefox versi 25.0

\section{Client}

1. Perangkat Keras

a. PC Client dengan spesifikasi minimal sebagai berikut :

1) Processor Intel ${ }^{\circledR}$ Core $^{\mathrm{TM}} 2$ CPU T5500@ $1.66 \mathrm{GHz}$

2) Harddisk $120 \mathrm{~GB}$

3) $R A M 1 \mathrm{~GB}$

4) $V G A 128 \mathrm{MB}$

b. Smartphone dan Tablet dengan spesifikasi minimal sebagai berikut :
1) Processor Quad Core ${ }^{\mathrm{TM}} @ 1.2 \mathrm{GHz}$
2) Memory Internal $2 \mathrm{~GB}$
3) $R A M 500 \mathrm{MB}$

2. Perangkat Lunak
a. Ubuntu versi 12.04
b. Microsoft Windows XP Professional versi 5.1
c. Mozilla Firefox versi 25.0
d. Android Gingerbread versi 4.0

\section{Network}

1. Arsitektur jaringan : Client server

2. Jenis jaringan : Internet

3. Bandwith internet $: 2 \mathrm{Mbps}$

\section{Pengembangan Sistem}

Dalam pengembangan sistem e-learning di STT Terpadu Nurul Fikri, terdapat serangkaian langkahlangkah yang penulis lakukan dalam pengembangan sistem tersebut, antara lain :

1. Meminta masukan yang diperlukan untuk kebutuhan pengembangan sistem e-learning.

2. Menginstalasi sistem e-learning menggunakan moodle versi 2.9 daan theme Klass di server local.

3. Menambahkan menu dan mengatur letak block sesuai kebutuhan pengguna. 
4. Meng-import data user dari sistem e-learning yang lama ke sistem e-learning yang telah dikembangkan.

5. Membuat matakuliah dan mengatur enrolment user.

6. Meng-upload materi perkuliahan dari sistem $e$ learning yang lama ke sistem e-learning yang telah dikembangkan.

7. Menguji sistem e-learning yang telah dikembangkan secara keseluruhan.

8. Me-launcing sistem e-learning tersebut ke server utama.

\section{Cutover}

Pada bagian ini akan dijelaskan mengenai fase akhir yaitu cutover yang meliputi pengujian sistem dan launching sistem.

\section{Pengujian Sistem}

Sebelum sistem e-learning yang telah dikembangkan diterapkan, maka sistem tersebut harus bebas dari segala kesalahan, diperlukan pengujian sistem untuk menemukan kesalahan yang mungkin terjadi. Pengujian sistem yang dilakukan meliputi pengujian terhadap seluruh aktifitas yang dilakukan oleh pengguna (fungsionalitas). Adapun pengujian sistem tersebut akan dijelaskan pada tabel berikut :

Tabel.7 Pengujian Sistem

\begin{tabular}{|c|l|l|l|}
\hline No & Nama Tes & \multicolumn{1}{|c|}{$\begin{array}{c}\text { Hasil yang } \\
\text { diharapkan }\end{array}$} & Hasil \\
\hline 1 & $\begin{array}{l}\text { Meng- } \\
\text { upload user }\end{array}$ & $\begin{array}{l}\text { User admin dapat } \\
\text { meng-upload user } \\
\text { untuk menambahkan } \\
\text { user baak, dosen dan } \\
\text { mahasiswa. }\end{array}$ & Sesuai \\
\hline 2 & $\begin{array}{l}\text { Membuat } \\
\text { informasi }\end{array}$ & $\begin{array}{l}\text { User admin dan baak } \\
\text { dapat membuat } \\
\text { informasi untuk dosen } \\
\text { dan mahasiswa. }\end{array}$ & Sesuai \\
\hline 3 & $\begin{array}{l}\text { Melihat } \\
\text { informasi }\end{array}$ & $\begin{array}{l}\text { User dosen dan } \\
\text { mahasiswa dapat } \\
\text { melihat informasi } \\
\text { yang dibuat oleh } \\
\text { admin dan baak. }\end{array}$ & Sesuai \\
\hline 4 & $\begin{array}{l}\text { Membuat } \\
\text { matakuliah }\end{array}$ & $\begin{array}{l}\text { User } \text { admin dapat } \\
\text { membuat matakuliah } \\
\text { untuk dosen dan }\end{array}$ & Sesuai \\
\hline
\end{tabular}

\begin{tabular}{|c|c|c|c|}
\hline No & Nama Tes & $\begin{array}{c}\text { Hasil yang } \\
\text { diharapkan }\end{array}$ & Hasil \\
\hline & & mahasiswa. & \\
\hline 5 & $\begin{array}{l}\text { Meng-enrol } \\
\text { matakuliah }\end{array}$ & $\begin{array}{l}\text { User mahasiswa dapat } \\
\text { meng-enrol } \\
\text { matakuliah yang } \\
\text { dibuat oleh admin. }\end{array}$ & Sesuai \\
\hline 6 & $\begin{array}{l}\text { Mengakses } \\
\text { matakuliah }\end{array}$ & $\begin{array}{l}\text { User dosen dan } \\
\text { mahasiswa dapat } \\
\text { mengakses matakuliah } \\
\text { yang dibuat oleh } \\
\text { admin. }\end{array}$ & Sesuai \\
\hline 7 & $\begin{array}{l}\text { Meng- } \\
\text { upload } \\
\text { materi }\end{array}$ & $\begin{array}{l}\text { User dosen dapat } \\
\text { meng-upload materi } \\
\text { untuk di-download } \\
\text { oleh mahasiswa. }\end{array}$ & Sesuai \\
\hline 8 & $\begin{array}{l}\text { Men- } \\
\text { download } \\
\text { materi }\end{array}$ & $\begin{array}{l}\text { User mahasiswa dapat } \\
\text { men-download materi } \\
\text { yang di-upload oleh } \\
\text { dosen. }\end{array}$ & Sesuai \\
\hline 9 & $\begin{array}{l}\text { Membuat } \\
\text { kuis }\end{array}$ & $\begin{array}{l}\text { User dosen dapat } \\
\text { membuat kuis untuk } \\
\text { diikuti oleh } \\
\text { mahasiswa. }\end{array}$ & Sesuai \\
\hline 10 & $\begin{array}{l}\text { Mengikuti } \\
\text { kuis }\end{array}$ & $\begin{array}{l}\text { User mahasiswa dapat } \\
\text { mengikuti kuis yang } \\
\text { dibuat oleh dosen. }\end{array}$ & Sesuai \\
\hline 11 & $\begin{array}{l}\text { Membuat } \\
\text { upload } \\
\text { tugas }\end{array}$ & $\begin{array}{l}\text { User dosen dapat } \\
\text { membuat upload tugas } \\
\text { untuk mahasiswa. }\end{array}$ & Sesuai \\
\hline 12 & $\begin{array}{l}\text { Meng- } \\
\text { upload } \\
\text { tugas }\end{array}$ & $\begin{array}{l}\text { User mahasiswa dapat } \\
\text { meng-upload tugas } \\
\text { yang dibuat oleh } \\
\text { dosen. }\end{array}$ & Sesuai \\
\hline
\end{tabular}

\section{Launching Sistem}

Setelah pengujian sistem telah dilakukan, maka tahapan akhir dari pengembangan sistem e-learning yang telah dikembangkan ialah me-launching sistem tersebut ke server utama dengan persetujuan pihak Puket I Bidang Akademik STT Terpadu Nurul Fikri. Tahapan launching sistem dilakukan dengan memindahkan data-data sistem e-learning yang telah dikembangkan pada server local ke server utama yang terletak di Kampus B STT Terpadu Nurul Fikri dengan menggunakan alamat url berikut : http://elen.nurulfikri.ac.id/.

\section{Hasil Implementasi}

Pada bagian ini akan dijelaskan mengenai hasil dari implementasi sistem e-learning yang telah 
dikembangkan meliputi page home sebelum login, page home admin, page upload users admin, page add matakuliah admin, page home baak, page add information baak, page home dosen, page my courses dosen, page matakuliah dosen, page home mahasiswa, page online courses mahasiswa, page enrolment mahasiswa, page my courses mahasiswa dan page matakuliah mahasiswa.

\section{Page Home Sebelum Login}

Pada page home sebelum login, sistem e-learning hanya akan menampilkan informasi mengenai sistem $e$ learning dan menu untuk mengakses sistem informasi lainnya yang ada di STT Terpadu Nurul Fikri. Adapun main menu yang ditampilkan hanya dapat diakses ketika user telah login ke dalam sistem e-learning menggunakan username dan password.

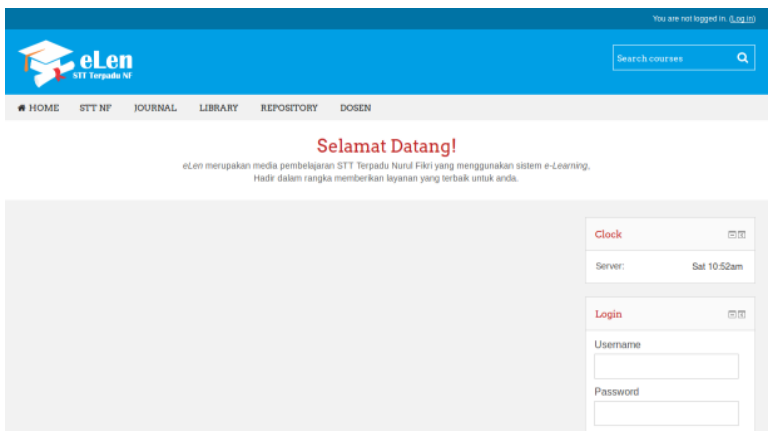

Gambar 6. Page Home Sebelum Login

\section{Page Home Admin}

Pada page home admin, sistem e-learning akan menampilkan menu yang dapat digunakan admin sebagai user yang memilki wewenang tertinggi untuk membuat informasi, meng-upload user dan membuat matakuliah.

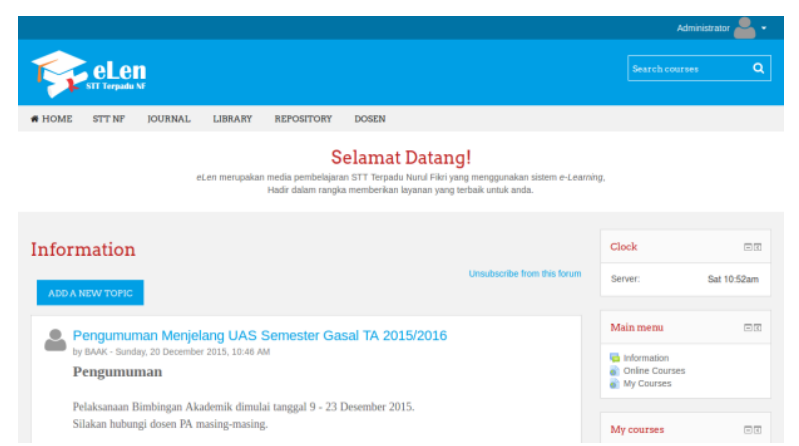

Gambar.7 Page Home Admin

\section{Page Upload Users Admin}

Pada page upload users admin, sistem e-learning akan menampilkan page yang dapat digunakan oleh admin untuk meng-upload user.

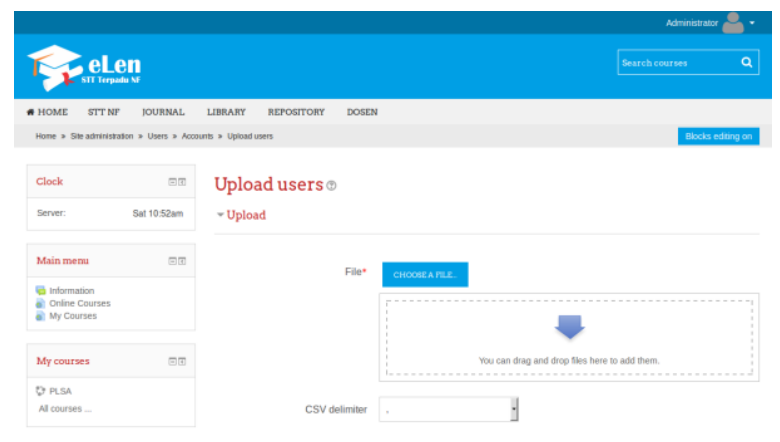

Gambar.8 Page Upload Users Admin

\section{Page Add Course Admin}

Pada page add course admin, sistem e-learning akan menampilkan page yang dapat digunakan oleh admin untuk membuat matakuliah.

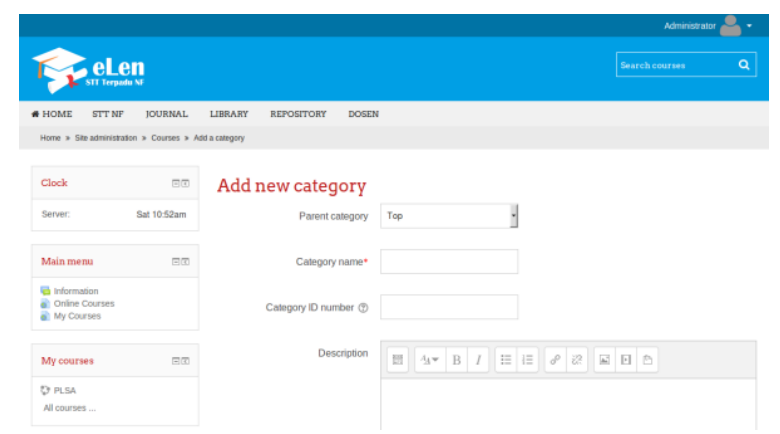

Gambar.9 Page Add Course Admin

\section{Page Home Baak}

Pada page home baak, sistem e-learning akan menampilkan menu yang hanya dapat digunakan baak untuk membuat informasi.

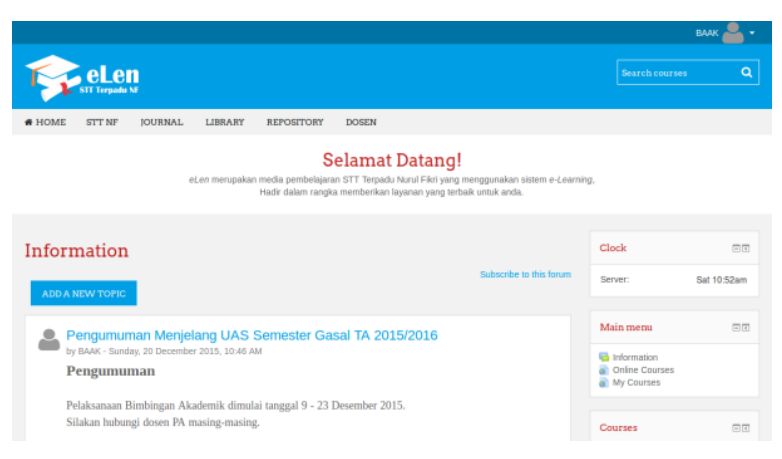

Gambar.10 Page Home Baak 


\section{Page Add Informartion Baak}

Pada page add information baak, sistem e-learning akan menampilkan page yang dapat digunakan oleh baak untuk membuat informasi.

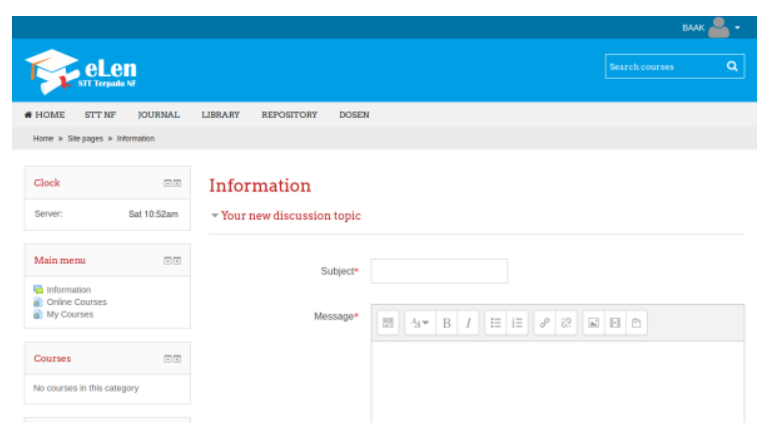

Gambar.11 Page Add Information Baak

\section{Page Home Dosen}

Pada page home dosen, sistem e-learning akan menampilkan menu yang dapat digunakan dosen untuk melihat informasi, mengakses matakuliah.

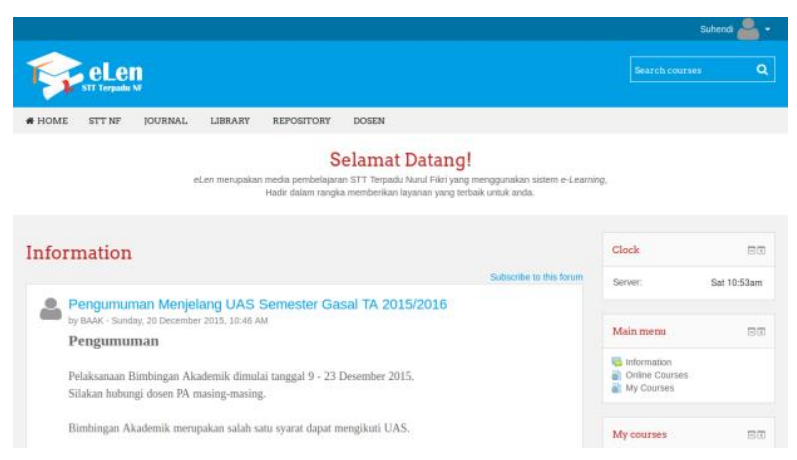

Gambar.12 Page Home Dosen

\section{Hasil Evaluasi}

Pada bagian ini akan dijelaskan mengenai hasil evaluasi yang meliputi perbandingan sistem e-learning, requirement dan implementasi sistem e-learning dan kuesioner setelah pengembangan.

\section{Perbandingan Sistem E-Learning}

Berikut ini adalah perbandingan dari beberapa sistem e-learning sebagai benchmark dalam pengembangan sistem e-learning di STT Terpadu Nurul Firki :
Tabel.8 Perbandingan sistem e-learning

\begin{tabular}{|c|c|c|c|c|}
\hline \multirow[b]{2}{*}{ No } & \multirow[b]{2}{*}{ Features } & \multicolumn{3}{|c|}{ Sistem E-Learning } \\
\hline & & $\begin{array}{l}\text { Universitas } \\
\text { Indonesia }\end{array}$ & STMIK Amikom & $\begin{array}{l}\text { STT Terpadu } \\
\text { Nurul Fikri }\end{array}$ \\
\hline 1 & Website & scele.ui.ac.id & elearning amikom.ac.id & elen.nurulfikri.ac.id \\
\hline 2 & Responsive & प & D & प \\
\hline 3 & $\begin{array}{l}\text { Others } \\
\text { menu }\end{array}$ & (a & Q & Q \\
\hline 4 & $\begin{array}{l}\text { Online } \\
\text { course }\end{array}$ & $\bar{\square}$ & $\bar{\square}$ & $\bar{\square}$ \\
\hline 5 & My course & प & D & Q \\
\hline 6 & $\begin{array}{l}\text { Request } \\
\text { course }\end{array}$ & 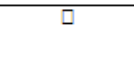 & $\square$ & $\square$ \\
\hline 7 & $\begin{array}{l}\text { Google } \\
\text { scholar } \\
\text { search }\end{array}$ & (] & प & प \\
\hline 8 & Forum & प & प & प] \\
\hline 9 & Assignment & $\square$ & $\overline{0}$ & प \\
\hline 10 & $\begin{array}{l}\text { Documents } \\
\text { share }\end{array}$ & प & प & प \\
\hline 11 & Quiz & (] & प & प \\
\hline 12 & $\begin{array}{l}\text { Pop up } \\
\text { notification }\end{array}$ & प & D & Q \\
\hline
\end{tabular}

Berdasarkan uraian penjelasan dari tabel tersebut, maka dapat disimpulkan bahwa fitur yang terdapat pada sistem e-learning di STT Terpadu Nurul Fikri yang telah dikembangkan lebih baik dibandingkan dengan sistem e-learning lainnya di Universitas Indonesia dan STMIK Amikom.

\section{Requirement dan Implementasi Sistem E-Learning}

Berikut ini adalah hasil dari requirement dan implementasi sistem e-learning di STT Terpadu Nurul Fikri yang telah dikembangkan :

Tabel.9 Requerement dan implementasi sistem elearning

\begin{tabular}{|c|c|c|c|}
\hline \multirow{2}{*}{ No } & \multicolumn{2}{|c|}{ Sistem E-Learning } & \multirow{2}{*}{ Hasil } \\
\hline & Requirement & Implementasi & \\
\hline 1 & $\begin{array}{l}\text { Instalasi moodle } \\
\text { yang sudah } \\
\text { responsive. }\end{array}$ & $\begin{array}{c}\text { Menggunakan } \\
\text { moodle versi } 2.9 .\end{array}$ & Sesuai \\
\hline 2 & $\begin{array}{c}\text { Instalasi theme } \\
\text { bernuansa STT } \\
\text { Terpadu Nurul } \\
\text { Fikri. }\end{array}$ & $\begin{array}{l}\text { Menggunakan } \\
\text { theme Klass. }\end{array}$ & Sesuai \\
\hline 3 & $\begin{array}{l}\text { Adanya menu } \\
\text { akses ke sistem } \\
\text { informasi } \\
\text { lainnya. }\end{array}$ & $\begin{array}{l}\text { Menambahkan } \\
\text { menu sistem } \\
\text { informasi } \\
\text { lainnya. } \\
\end{array}$ & Sesuai \\
\hline 4 & $\begin{array}{c}\text { Adanya menu } \\
\text { akes ke } \\
\text { matakuliah yang }\end{array}$ & $\begin{array}{l}\text { Menambahkan } \\
\text { menu my } \\
\text { courses. }\end{array}$ & Sesuai \\
\hline
\end{tabular}




\begin{tabular}{|c|c|c|c|}
\hline \multirow{2}{*}{ No } & \multicolumn{2}{|c|}{ Sistem $\boldsymbol{E}$-Learning } & \multirow{2}{*}{ Hasil } \\
\cline { 2 - 3 } & Requirement & Implementasi & \\
\hline \multirow{2}{*}{ telah diambil } & & \\
& pengguna. & & \\
& $\begin{array}{c}\text { Adanya } \text { menu } \\
\text { mendaftar } \\
\text { matakuliah oleh } \\
\text { dosen. }\end{array}$ & $\begin{array}{c}\text { Menambahkan } \\
\text { menu request } \\
\text { course. }\end{array}$ & Sesuai \\
\hline 6 & Data user & Meng-import & Sesuai \\
& berdasarkan & data user dari & \\
& sistem -learning & sistem - & \\
& yang lama. & learning yang & \\
& lama. & \\
\hline 7 & Matakuliah & Membuat & Sesuai \\
& berdasarkan & matakuliah & \\
& sistem -learning & untuk tahun & \\
& yang lama. & ajaran & \\
& & 2014/2015. & \\
\hline 8 & Materi & Meng-upload & Sesuai \\
& perkuliahan & materi & \\
& berdasarkan & perkuliahan & \\
& sistem $e$-learning & untuk tahun & \\
& yang lama. & ajaran & \\
& & 2014/2015. & \\
\hline
\end{tabular}

Berdasarkan uraian penjelasan dari tabel tersebut, maka dapat disimpulkan bahwa requirement yang diperlukan untuk kebutuhan pengembangan sistem $e$ learning sudah sesuai dengan implementasi sistem $e$ learning di STT Terpadu Nurul Fikri yang telah dikembangkan.

\section{Kuesioner Setelah Pengembangan}

Perhitungan kuesioner pada sistem e-learning di STT Terpadu Nurul Fikri yang telah dikembangkan menggunakan metode penilaian skala Likert dilakukan dengan menentukan skor jawaban terlebih dahulu. Adapun skor jawaban kuesioner tersebut akan dijelaskan pada tabel berikut :

Tabel 10. Skor Jawaban Kuesioner

\begin{tabular}{|c|l|c|}
\hline No & \multicolumn{1}{|c|}{ Alternatif Jawaban } & Skor \\
\hline 1 & Sangat Setuju & 4 \\
\hline 2 & Setuju & 3 \\
\hline 3 & Tidak Setuju & 2 \\
\hline 4 & Sangat Tidak Setuju & 1 \\
\hline
\end{tabular}

Hasil responden dari 10 Dosen dan 40 Mahasiswa yang telah mengisi kuesioner :

1. Apakah anda setuju tampilan web dari sistem $e$ learning sudah menarik dan responsive?
Tabel.11 Pertanyaan 1

\begin{tabular}{|c|l|c|c|}
\hline No & $\begin{array}{c}\text { Alternatif } \\
\text { Jawaban }\end{array}$ & Jumlah & Persentase \\
\hline 1 & Sangat Setuju & 11 & $22 \%$ \\
\hline 2 & Setuju & 34 & $68 \%$ \\
\hline 3 & Tidak Setuju & 5 & $10 \%$ \\
\hline 4 & $\begin{array}{l}\text { Sangat Tidak } \\
\text { Setuju }\end{array}$ & 0 & $0 \%$ \\
\hline \multicolumn{2}{|c|}{ Total } & $\mathbf{5 0}$ & $\mathbf{1 0 0} \%$ \\
\hline
\end{tabular}

Interpretasi skor soal no. 1 : (156/200) x $100=78$ $\%$

2. Apakah anda setuju pengaturan letak block (Clock, Login, Main menu) sudah sesuai dengan kebutuhan anda sebagai pengguna?

Tabel.12 Pertanyaan 2

\begin{tabular}{|c|l|c|c|}
\hline No & \multicolumn{1}{|c|}{$\begin{array}{c}\text { Alternatif } \\
\text { Jawaban }\end{array}$} & Jumlah & Persentase \\
\hline 1 & Sangat Setuju & 9 & $18 \%$ \\
\hline 2 & Setuju & 31 & $62 \%$ \\
\hline 3 & Tidak Setuju & 10 & $20 \%$ \\
\hline 4 & $\begin{array}{l}\text { Sangat Tidak } \\
\text { Setuju }\end{array}$ & 0 & $0 \%$ \\
\hline \multicolumn{2}{|c|}{ Total } & $\mathbf{5 0}$ & $\mathbf{1 0 0} \%$ \\
\hline
\end{tabular}

Interpretasi skor soal no. $2:(149 / 200) \times 100=$ $74.5 \%$

3. Apakah anda setuju penambahan menu (My Courses) sudah mempermudah anda dalam mengakses matakuliah yang telah diambil?

Tabel.13. Pertanyaan 3

\begin{tabular}{|c|l|c|c|}
\hline No & \multicolumn{1}{|c|}{$\begin{array}{c}\text { Alternatif } \\
\text { Jawaban }\end{array}$} & Jumlah & Persentase \\
\hline 1 & Sangat Setuju & 17 & $34 \%$ \\
\hline 2 & Setuju & 29 & $58 \%$ \\
\hline 3 & Tidak Setuju & 4 & $8 \%$ \\
\hline 4 & $\begin{array}{l}\text { Sangat Tidak } \\
\text { Setuju }\end{array}$ & 0 & $0 \%$ \\
\hline \multicolumn{2}{|c|}{ Total } & $\mathbf{5 0}$ & $\mathbf{1 0 0} \%$ \\
\hline
\end{tabular}

Interpretasi skor soal no. 3 : (163 / 200) $\mathrm{x}$ $100=81.5 \%$

4. Apakah anda setuju penambahan menu (Journal, Library, Repository, dll.) sudah mempermudah anda dalam mengakses sistem informasi lainnya yang ada di STT Terpadu Nurul Fikri?

Tabel.13 Pertanyaan 4

\begin{tabular}{|c|c|c|c|}
\hline No & $\begin{array}{c}\text { Alternatif } \\
\text { Jawaban }\end{array}$ & Jumlah & Persentase \\
\hline 1 & Sangat Setuju & 19 & $38 \%$ \\
\hline
\end{tabular}




\begin{tabular}{|c|l|c|c|}
\hline No & $\begin{array}{l}\text { Alternatif } \\
\text { Jawaban }\end{array}$ & Jumlah & Persentase \\
\hline 2 & Setuju & 28 & $56 \%$ \\
\hline 3 & Tidak Setuju & 3 & $6 \%$ \\
\hline 4 & $\begin{array}{l}\text { Sangat Tidak } \\
\text { Setuju }\end{array}$ & 0 & $0 \%$ \\
\hline \multicolumn{2}{|c|}{ Total } & $\mathbf{5 0}$ & $\mathbf{1 0 0 \%}$ \\
\hline
\end{tabular}

Interpretasi skor soal no. $4:(166 / 200) \times 100=83$ $\%$

5. Apakah anda setuju pengembangan sistem $e$ learning yang telah dilakukan sudah sesuai dengan kebutuhan anda sebagai pengguna?

Tabel.14. Pertanyaan 5

\begin{tabular}{|c|l|c|c|}
\hline No & \multicolumn{1}{|c|}{$\begin{array}{c}\text { Alternatif } \\
\text { Jawaban }\end{array}$} & Jumlah & Persentase \\
\hline 1 & Sangat Setuju & 13 & $26 \%$ \\
\hline 2 & Setuju & 27 & $54 \%$ \\
\hline 3 & Tidak Setuju & 10 & $20 \%$ \\
\hline 4 & $\begin{array}{l}\text { Sangat Tidak } \\
\text { Setuju }\end{array}$ & 0 & $0 \%$ \\
\hline \multicolumn{2}{|c|}{ Total } & $\mathbf{5 0}$ & $\mathbf{1 0 0} \%$ \\
\hline
\end{tabular}

Interpretasi skor soal no. $5:(153 / 200) \times 100=$ $76.5 \%$

Penilaian skala Likert untuk interpretasi keseluruhan skor dari soal no. 1 sampai dengan $5:(78+74.5+$ $81.5+83+76.5) / 5=78.7 \%$

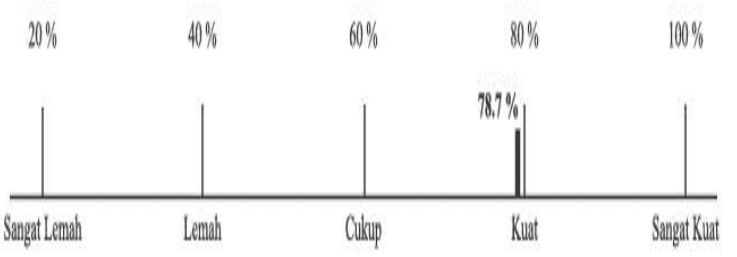

Gambar.13 Hasil Perhitungan Kuesioner

Berdasarkan hasil penilaian kuesioner tersebut, maka dapat disimpulkan bahwa sistem e-learning di STT Terpadu Nurul Fikri yang telah dikembangkan sudah efektif dengan tingkat evaluasi kepuasan pengguna diangka rata-rata $78.7 \%$ (kuat), dengan kata lain sistem e-learning tersebut sudah dapat dan layak diterapkan di STT Terpadu Nurul Fikri.

\section{KESIMPULAN}

Berdasarkan hasil penelitian yang telah penulis lakukan, maka dapat disimpulkan bahwa sistem $e$ learning di STT Terpadu Nurul Fikri yang telah dikembangkan : (1) Sudah sesuai dengan kebutuhan pengguna berdasarkan masukan yang diperlukan untuk kebutuhan pengembangan sistem e-learning; (2) Sudah efektif dengan tingkat evaluasi kepuasan pengguna diangka rata-rata $78.7 \%$ (kuat), berdasarkan hasil penilaian kuesioner setelah pengembangan sistem $e$ learning; dan (3) Sudah dapat diterapkan di STT Terpadu Nurul Fikri untuk tahun ajaran 2016/2017 berdasarkan keputusan dari pihak Puket I Bidang Akademik STT Terpadu Nurul Fikri yang dapat diakses melalui alamat url berikut : http://elen.nurulfikri.ac.id/.

\section{UCAPAN TERIMA KASIH}

Terima kasih kepada semua pihak yang telah mendukung tulisan ini terutama kepada : Ketua STT NF, Kepala LPPM STT NF, Kaprodi SI dan kaprodi TI serta segenap mahasiswa STT NF sehingga tulisan ini berjalan dengan baik dan lancar. Penelitian ini menjadi awal yang berkesinambungan dalam penelitian mengenai e-learning.

\section{DAFTAR PUSTAKA}

1. Suhendi, “Analisa Penggunaan E-learning Untuk Meningkatkan Kemudahan Mahasiswa Dalam Pembelajaran", Seminar Nasional Teknologi Informasi dan Multimedia, 2015

2. Jogiyanto, HM. Analisa dan Desain Sistem Informasi : Yogyakarta, 2005.

3. Gordon, B. Kerangka Dasar Sistem Informasi Manajamen : Jakarta, 1991.

4. Kusmana, A. E-Learning dalam Pembelajaran : Jurnal Lentera Pendidikan, 2011.

5. Gora, Winastaman. Produksi CD Multimedia Interaktif : Yogyakarta, 2007.

6. Sudirman, N. Kelebihan dan Kekurangan ELearning

http://nurlindasudirman.blogspot.com/2012/01/ke lebihan-dan-kekurangan-e-learning.html/, 2012. (26 September 2015) 
7. Yanto, Rudi. Analisa dan Perancangan Sistem Pembelajaran Menggunakan E-Learning : Jakarta, 2007.

8. Amiroh. Mengintip Berbagai Jenis Platform ELearning : http://amiroh.web.id/mengintipberbagai-jenis-platform-e-learning/, 2013. (26 September 2015)

9. Glossary. Glossary Of E-learning Terms : LearnFrame.com, 2001.

10. Cole, Jason. Using Moodle : O'Reily USA, 2005.

11. Amiroh. Membangun E-Learning dengan Learning Management System Moodle : Sidoarjo, 2012.

12. Kendall, Kenneth \& Jullie E. System Analysis and Design : New Jersey, 2008.

13. Whitten, Jeffrey L, Loonie D \& Kevin C. Systems Analysis and Design Methods : New York, 2004.

14. Nugroho, Adi. Rekaya Perangkat Lunak Berorientasi Objek Dengan Metode USDP : Yogyakarta, 2010.

15. Munawar. Pemodelan Visual dengan $U M L$ : Yogyakarta, 2005.

16. Agustina, Fenni. Unified Modelling Language : Jakarta, 2008.

17. Suhendi. Pengembangan Sistem Pembelajaran Secara Online pada Sekolah Sumbangsih Jakarta : Jakarta, 2011.

18. Ihsan, Hamdi. Pengembangan E-Learning System pada Aplikasi Bimbel Online di 2tors.com : Ciputat 2010.

19. Chusni R, Iqbal. Pengembangan Aplikasi ELearning Berbasis Moodle di SMA 2 Mei Ciputat : Ciputat, 2011. 